\title{
Long-term tillage and drainage influences on greenhouse gas fluxes from a poorly drained soil of central Ohio
}

\author{
S. Kumar, T. Nakajima, A. Kadono, R. Lal, and N. Fausey
}

\begin{abstract}
Intensive tillage practices and poorly drained soils of the Midwestern United States are one of the prime reasons for increased greenhouse gas (GHG) fluxes from agriculture. The naturally poorly drained soils prevalent in this region require subsurface drainage for improving aeration and reducing GHG fluxes from soils. However, very little research has been conducted on the combination of tillage and drainage impacts on GHG fluxes from poorly drained soils. Thus, the present study was conducted in central Ohio with specific objective to assess the influences of long-term (18-year) no-tillage (NT) and chisel-till (CT) impacts on carbon dioxide $\left(\mathrm{CO}_{2}\right)$, nitrous oxide $\left(\mathrm{N}_{2} \mathrm{O}\right)$, and methane $\left(\mathrm{CH}_{4}\right)$ fluxes from the soils in plots managed under drained (D) or nondrained (ND) conditions. The experimental site was established on a poorly drained Crosby silt loam soil in 1994 under corn (Zea mays L.)-corn rotation. Measurements of soil $\mathrm{CO}_{2}, \mathrm{~N}_{2} \mathrm{O}$, and $\mathrm{CH}_{4}$ fluxes were conducted biweekly during 2011 and 2012 using the static chamber technique. In 2011, the annual $\mathrm{CO}_{2}-\mathrm{C}$ and $\mathrm{N}_{2} \mathrm{O}-\mathrm{N}$ from NT were $18 \%$ and $83 \%$, respectively, lower compared to CT. Similar trends were observed for 2012. Methane fluxes were highly variable in both years. Tillage and drainage influenced seasonal soil GHG emissions; however, differences were not always significant. In general, plots under NT with subsurface drainage produced lower emissions compared to those under CT. Subsurface drainage lowered the emissions compared to those under ND. Results from this study concluded that subsurface drainage in poorly drained soils with long-term NT practice can be beneficial for the environment by emitting lower GHG fluxes compared to tilled soils with no drainage. However, long-term monitoring of these fluxes under diverse cropping systems under poorly drained soils is needed.
\end{abstract}

Key words: chisel tillage—corn—greenhouse gas—no-tillage—soil organic carbon—subsurface drainage

Agricultural land, covering $37 \%$ of the earth's land surface (Smith et al. 2008), is responsible for a significant amount (12\%) of the total greenhouse gas (GHG) emissions to Earth's atmosphere (Linquist et al. 2012) that include carbon dioxide $\left(\mathrm{CO}_{2}\right)$, methane $\left(\mathrm{CH}_{4}\right)$, and nitrous oxide $\left(\mathrm{N}_{2} \mathrm{O}\right)$ (Cole et al. 1997; Paustian 2004). Worldwide, agricultural soils contribute $60 \%$ to $80 \%$ to the anthropogenic sources (Syakila and Kroeze 2011), and account for 60\% and $50 \%$ of global $\mathrm{N}_{2} \mathrm{O}$ and $\mathrm{CH}_{4}$ emissions, respectively (Smith et al.2007). The $\mathrm{CO}_{2}$ concentration in the atmosphere has increased by approximately $35 \%$ since the start of industrial revolution and is predicted to reach $700 \mathrm{ppmv}$ by the end of this century (IPCC 2001a). Soil because of tillage operations affects soil biochemical and physical properties, consequently influencing the soil $\mathrm{CO}_{2}$ fluxes (Oorts et al. 2007). No-tillage (NT) is one of several management practices used for increasing SOC and reducing GHG fluxes from agroecosystems. In general, NT restores soil carbon (C) levels through the retention and incorporation of crop residues and the reduction in high-disturbance cultivation. This subsequently reduces overall GHG emissions through a reduction in farm machinery operations (Maraseni and Cockfield 2011)

No-tillage systems are sometimes not effective if soils are poorly drained or under water logged conditions during the cropping season. Rochette (2008) reported that NT increases $\mathrm{N}_{2} \mathrm{O}$ emissions from poorly drained soils due to increased denitrification. High soil moisture content usually creates anaerobic conditions and hence enhances denitrification rates in NT compared to tilled soils (Arah et al. 1991). Subsurface drainage is, therefore, adopted in agricultural systems to remove excess water from the soils in order to increase trafficability and enhance crop productivity (Drury et al. 1993). Further, subsurface drainage controls the denitrification in the soils which is strongly influenced by soil nitrate $\left(\mathrm{NO}_{3}\right)$ levels, crop residue available, soil moisture content, aeration, soil $\mathrm{pH}$, and temperature. It has been reported that about $30 \%$ of nitrogen $(\mathrm{N})$ applied to agricultural soils can be lost through leaching (Ronen et al. 1988) if these soils are not properly managed. Subsurface drainage allows timely farm operations (Nangia et al. 2010) especially in poorly drained soils. It increases the movement of excess water from the fields and reduces the biochemical

and land management practices influence the organic carbon (SOC) content of the soils (McConkey et al. 2003; Osher et al. 2003; Paustian et al. 2000), and hence influence the GHG emissions (Lee et al. 2006; Paustian et al. 2000; Poch et al. 2006). One way of controlling these emissions is by expanding the terrestrial SOC sink by adopting conservation tillage (e.g., no-tillage) (Gregorich et al. 2005; Ussiri et al. 2009) and by draining excess water from cropland soils (Smith et al. 2003).

It is well known that intensive tillage practices strongly affect GHG emissions; however, these effects vary and depend on frequency of tillage, soil type, climate, other management practices, and litter accumulation (Six et al. 2004). Disturbance to soil
Sandeep Kumar is an assistant professor in the Department of Plant Science at South Dakota University in Brookings, South Dakota. Toru Nakajima is a postdoctoral researcher with the Carbon Management \& Sequestration Center in the School of Environment \& Natural Resources at The Ohio State University in Columbus, Ohio. Atsunobu Kadono is an associate professor at Tottori University of Environmental Studies in Tottori, Japan. Rattan Lal is a distinguisted professor and director of the Carbon Management \& Sequestration Center in the School of Environment \& Natural Resources at The Ohio State University in Columbus, Ohio. Norman Fausey is a supervisory research soil scientist and research leader with the USDA Agricultural Research Service in Columbus, Ohio. 
reduction of dissolved $\mathrm{N}_{2} \mathrm{O}$ in the soil profile (Mehnert et al. 2007). Soluble C compounds and $\mathrm{NO}_{3}-\mathrm{N}$ applied to the soil surface can leach downward, supplying substrate (electron donors) and terminal electron acceptors for denitrification to occur and produce the $\mathrm{N}_{2} \mathrm{O}$ that can easily be dissolved in soil water or ground water (Sawamoto et al. 2005). The higher amount of labile organic C (Hill and Cardaci 2004) and $\mathrm{NO}_{3}$ under anaerobic conditions enhance denitrification rates, whereas, aerobic conditions reduce denitrification rates (Myrold 1998).

About $33 \%$ of the cultivated area is tile-drained in the midwestern United States (Power et al. 2000) to improve aeration, increase availability of nutrients, and enhance the crop productivity (Cannell et al. 1985; Lal and Taylor 1970). The tile-drained system has now become a routine practice in the midwestern United States (Nangia et al. 2010). However, detailed research related to combination of tillage and tile-drainage system impacts on soil surface GHG fluxes in poorly drained soils is still lacking. Therefore, the present study was conducted based on the hypothesis that poorly drained soils, when managed with tile-drained and NT systems, will improve aeration, and decrease soil surface GHG fluxes. The major goal of the study was to investigate the effects of tillage and drainage systems on GHG emissions from a poorly drained soil of central Ohio.

\section{Materials and Methods}

Study Background and Experimental Design. The experimental plots were established in the summer of 1994 at the Waterman farm of The Ohio State University in Columbus $\left(40^{\circ} 02^{\prime} 29^{\prime \prime} \mathrm{N}, 8^{\circ} 02^{\prime} 68^{\prime \prime} \mathrm{W}\right)$, Ohio. Soils at the experimental site are classified as Crosby silt loam (fine, mixed, mesic, Aeric Ochraqualf) (Soil Survey Staff 1996). The study design was a factorial experiment which consisted of two tillage (NT and chisel-till [CT]) factors and two drainage (tile-drainage [D] and nondrainage [ND]) levels. Twelve research plots of $27.4 \mathrm{~m} \times 27.4 \mathrm{~m}(90 \mathrm{ft} \times$ $90 \mathrm{ft}$ ) size were divided into six pairs of CT and NT with each replication block containing four plots. These plots were separated by a $6.1 \mathrm{~m}(20 \mathrm{ft})$ grassed driveway on all sides. Treatments included NT-D, NT-ND, CT-D, and CT-ND. The CT consisted of fall chisel plowing to a depth of about $20 \mathrm{~cm}$ (7.87 in), and spring disking to prepare the

\section{Table 1}

Dates of crop management, fertilizer application, and other activities performed during the cropping season.

\begin{tabular}{ll}
\hline Activities & Details \\
\hline 2011 & \\
Crop & Corn (Zea mays L.) \\
Tillage date & March 21, 2011, and November 10, 2011 \\
Planting date & April 14, 2011 \\
Chemical fertilizer side dressing date & June 6, 2011 \\
& Nitrogen (168 kg N ha-1) \\
Chemical fertilizer and application rate & Potassium (224 kg K ha-1) \\
& Phosphorus (112 $\left.\mathrm{kg} \mathrm{P} \mathrm{ha}^{-1}\right)$ \\
Harvesting date & November 2, 2011 \\
Crop & \\
Tillage date & Corn (Zea mays L.) \\
Planting date & March 20, 2012 and November 5, 2012 \\
Chemical fertilizer side dressing date & April 30, 2012 \\
Chemical fertilizer and application rate & June 6, 2012 \\
Harvesting date & Nitrogen (168 kg N ha-1) \\
& Potassium 224 kg K ha-1) \\
& Phosphorus 112 kg P ha-1) \\
& October 16, 2012 \\
\end{tabular}

seedbed for planting. The experimental site is under continuous corn (Zea mays L.)-corn rotation. Subsurface drainage was installed using perforated corrugated plastic tubing (Sullivan 1997). The subsurface drainage tiles were $10 \mathrm{~cm}$ (3.94 in) in diameter and installed about $75 \mathrm{~cm}$ (29.5 in) deep, and 9.1 $\mathrm{m}(30 \mathrm{ft})$ apart with tiles flowing from west to east (Sullivan 1997).

The corn was planted in March every year and harvested in November. Detailed information about land management including planting date, fertilizer application, and other farming operations performed during two cropping seasons is provided in table 1 . The chemical fertilizer used for the crop was $168 \mathrm{~kg} \mathrm{~N} \mathrm{ha}{ }^{-1}\left(150 \mathrm{lb} \mathrm{ac}^{-1}\right), 224 \mathrm{~kg} \mathrm{~K} \mathrm{ha}^{-1}$ $\left(200 \mathrm{lb} \mathrm{ac}^{-1}\right)$, and $112 \mathrm{~kg} \mathrm{P} \mathrm{ha}^{-1}\left(100 \mathrm{lb} \mathrm{ac}^{-1}\right)$.

Soil Sampling and Analysis. Intact triplicate soil cores of $5 \mathrm{~cm}$ (1.97 in) diameter and $5 \mathrm{~cm}$ (1.97 in) height were collected from the 0 to $10 \mathrm{~cm}$ (0 to $3.94 \mathrm{in}$ ) depth of each plot during March of 2012 before corn planting. In addition, disturbed soil samples from the 0 to $10 \mathrm{~cm}$ (0 to $3.94 \mathrm{in}$ ) depth were also collected in triplicate from each plot. Disturbed soil samples and intact soil cores were labeled, trimmed from both ends (only intact core samples), sealed in plastic zip-lock bags, transported to the laboratory, and stored at $4^{\circ} \mathrm{C}\left(39.2^{\circ} \mathrm{F}\right)$ until measurements were taken. Soil textural analysis was done using the hydrometer method.
Soil bulk density (BD) was determined by the core method (Grossman and Reinsch 2002). The SOC and N concentration were determined by the dry combustion method $\left(900^{\circ} \mathrm{C}\left[1,652^{\circ} \mathrm{F}\right]\right)$ using a Vario Max $\mathrm{CN}$ Analyzer (Elementer Inc., Hanau, Germany).

Soil Surface Greenhouse Gas Flux Sampling. Measurements of soil surface GHGs $\left(\mathrm{CO}_{2}, \mathrm{~N}_{2} \mathrm{O}\right.$, and $\left.\mathrm{CH}_{4}\right)$ fluxes were made during 2011 and 2012 using the static chamber technique. A total of 12 chambers were installed at the experimental site under all the treatments in three replicates of each tillage treatment. The gas chambers were made of polyvinyl chloride (PVC) pipe and consisted of two parts: a bottom base $25 \mathrm{~cm}$ (9.84 in) high and $15 \mathrm{~cm}$ (5.91 in) diameter; and a lid with a gas sampling port as described by Jacinthe and Dick (1997). The gas samples were collected biweekly from March through late August of 2011 and March through November of 2012. Static chambers were inserted $5 \mathrm{~cm}$ (1.97 in) into the ground in all the plots and remained undisturbed during the entire monitoring period except for temporary removal when mechanized farm operations were performed. These gas chambers were kept closed during the air sample collection with the lid. The sample collection was done similar to Ussiri et al. (2009). The air samples from the chambers headspace were collected by a syringe (20 $\left.\mathrm{mL}\left[0.79 \mathrm{in}^{3}\right]\right)$ at 0,30 , and 60 minutes, and 
transferred to crimp sealed preevacuated $(<0.05 \mathrm{kPa}) 10 \mathrm{~mL}\left(0.39 \mathrm{in}^{3}\right)$ vials fitted with butyl rubber septa (Wheaton, Millsville, and New Jersey). Air temperature during the time of sampling for each chamber was used for calculating fluxes. The soil moisture and temperature readings were taken at the time of gas sampling.

The air samples were analyzed for gas concentration using gas chromatograph (Shimadzu GC 14A, Kyoto, Japan). This instrument is equipped with thermal conductivity detector and $3 \mathrm{~m}$ (9.84 ft) long by $0.3 \mathrm{~cm}$ (0.12 in) internal diameter Hayesep D column (Alltech, Deerfield, Illinois). Helium (He) was used as a carrier gas at a flow rate of $25 \mathrm{~cm}^{3} \mathrm{~min}^{-1}\left(1.526 \mathrm{in}^{3} \mathrm{~min}^{-1}\right)$. Daily gases flux ([F]; g CO $2-\mathrm{C} \mathrm{m}^{-2}$ day $^{-1}$ ) can be calculated as:

$F=\frac{\Delta g}{\Delta \mathrm{t}} \times \frac{V}{A} \times k$,

\section{$\Delta g$}

where $\frac{\Delta g}{\Delta t}$ is the linear change in gas concentrations inside the chamber $\left(\mathrm{g} \mathrm{CO}_{2}-\mathrm{C}\right.$ $\left.\mathrm{m}^{-3} \min ^{-1}\right), V$ is the chamber volume $\left(\mathrm{m}^{3}\right)$, $A$ is the surface area circumscribed by the chamber $\left(\mathrm{m}^{2}\right)$, and $k$ is the time conversion coefficient. A linear model was used for calculating flux for each gas measurements. In order to calculate the global warming potential (GWP) in $\mathrm{CO}_{2}$-equivalent per hectare per year, the GWP for $\mathrm{N}_{2} \mathrm{O}$ was also calculated using the IPCC factor of 296, whereas, GWP for $\mathrm{CH}_{4}$ was calculated using Intergovernmental Panel on Climate Change (IPCC) factor of 23 (IPCC 2001b; Ussiri et al. 2009).

Statistical Analysis. A test for the homogeneity of variance was conducted to evaluate the variability of the differences between soil surface GHG fluxes within the NT vs. CT systems, and between D vs. ND systems. An analysis of variance (ANOVA) was further conducted with the SAS (2007) software. An estimate for the least significant difference (Duncan's least significant difference [LSD]) between treatments was obtained using the Mixed procedure in SAS. Statistical differences were declared significant at the $\alpha=0.05$ level. Soil surface gas fluxes monitored from March 1, 2011, through August 28,2011 , are referred to as the 2011 measurement year, and from March 1, 2012, to November 28, 2012, as 2012 measurement year. Further, gas measurements from March through May are referred to as spring, June

\section{Table 2}

Selected soil physical and chemical properties measured for the surface o to $10 \mathrm{~cm}$ depth at the experimental site.

\begin{tabular}{|c|c|c|c|c|}
\hline & Treatments & & & \\
\hline Soil properties & No-tillage & Chisel-till & Drainage & Nondrainage \\
\hline Sand $\left(\mathrm{g} \mathrm{kg}^{-1}\right)$ & 580 & 574 & 565 & 589 \\
\hline Silt $\left(\mathrm{g} \mathrm{kg}^{-1}\right)$ & 297 & 318 & 318 & 297 \\
\hline Clay $\left(\mathrm{g} \mathrm{kg}^{-1}\right)$ & 123 & 108 & 117 & 114 \\
\hline Soil texture & Sandy loam & Sandy loam & Sandy loam & Sandy loam \\
\hline Bulk density $\left(\mathrm{Mg} \mathrm{m}^{-3}\right)$ & 1.41 & 1.45 & 1.39 & 1.47 \\
\hline Soil organic carbon $\left(\mathrm{g} \mathrm{kg}^{-1}\right)$ & 15.9 & 15.3 & 14.8 & 16.4 \\
\hline Total nitrogen $\left(\mathrm{g} \mathrm{kg}^{-1}\right)$ & 1.6 & 1.54 & 1.47 & 1.63 \\
\hline Carbon/nitrogen ratio & 10.07 & 9.98 & 10.04 & 10.01 \\
\hline $\mathrm{pH}$ & 5.70 & 5.03 & 5.46 & 5.27 \\
\hline Electrical conductivity $\left(\mu \mathrm{S} \mathrm{cm}^{-1}\right)$ & 240 & 169 & 237 & 172 \\
\hline
\end{tabular}

through August referred to as summer, September through November referred to as autumn, and December through February referred to as winter.

\section{Results and Discussion}

Soil Physical and Chemical Properties. The basic selected soil physical and chemical properties for the surface 0 to $10 \mathrm{~cm}$ (3.94 in) depth of the experimental plots are shown in table 2. Soils at the experimental site were sandy loam. The soil BD for the 0 to $10 \mathrm{~cm}$ (3.94 in) depth ranged from 1.39 $\mathrm{Mg} \mathrm{m}^{-3}$ (86.8 $\mathrm{lb} \mathrm{ft}^{-3}$ drainage plots; to 1.47 $\mathrm{Mg} \mathrm{m}^{-3} 91.8 \mathrm{lb} \mathrm{ft}^{-3}$ nondrainage plots; table 2). The BD for soils under NT $\left(1.45 \mathrm{Mg} \mathrm{m}^{-3}\right.$ [90.6 $\left.\left.\mathrm{lb} \mathrm{ft}^{-3}\right]\right)$ plots was $1.4 \%$ lower as compared to that under CT $\left(1.47 \mathrm{Mg} \mathrm{m}^{-3}[91.8\right.$ $\left.\mathrm{lb} \mathrm{ft}^{-3}\right]$ ) plots. Soils were slightly acidic with $\mathrm{pH}$ varying from 5.03 to 5.70 . The calcium carbonate $\left(\mathrm{CaCO}_{3}\right)$ content of samples was about $0.1 \%$; therefore, soil inorganic $\mathrm{C}$ was ignored and total $\mathrm{C}$ was considered as the SOC (Kumar et al. 2012). The SOC concentrations in 2012 for the surface 0 to $10 \mathrm{~cm}(0$ to $3.94 \mathrm{in}$ ) depth were $4 \%$ higher under NT (15.9 $\mathrm{g} \mathrm{kg}^{-1}$ [1.526 $\left.\mathrm{in}^{3} \mathrm{~min}^{-1}\right]$; 1.59\%) compared to that under CT $\left(15.3 \mathrm{~g} \mathrm{~kg}^{-1}\right.$ [0.2448 in $\left.^{3} \mathrm{~min}^{-1}\right] ; 1.53 \%$ ) plots. Nondrainage (16.4 $\left.\mathrm{g} \mathrm{kg}^{-1}\left[0.2624 \mathrm{in}^{3} \mathrm{~min}^{-1}\right] ; 1.64 \%\right)$ treatment increased the SOC for the surface depth by $11 \%$ as compared to that under drainage (14.8 $\mathrm{g} \mathrm{kg}^{-1}$ [0.2368 in $\left.\mathrm{min}^{-1}\right] ; 1.48 \%$ ) system. Similar trend was observed for the total $\mathrm{N}$ content with higher values observed for NT vs. CT, and ND vs. D systems. The electrical conductivity values range from 172 to $240 \mu \mathrm{S} \mathrm{cm}^{-1}$ (67.72 to $94.49 \mu \mathrm{mho} \mathrm{in}^{-1}$ ).

Climate Data. The average daily precipitation and air temperature for 2011 were 3.65 $\mathrm{mm}(0.14 \mathrm{in})$ and $15.1^{\circ} \mathrm{C}\left(59.2^{\circ} \mathrm{F}\right)$, respec- tively (figure 1). The experimental site has a long-term (25 years) average temperature of $11.5^{\circ} \mathrm{C}\left(52.7^{\circ} \mathrm{F}\right)$ and annual precipitation of $1,039 \mathrm{~mm}$ (41 in). In 2011, average temperature and annual precipitation were $12.4^{\circ} \mathrm{C}$ $\left(54.3^{\circ} \mathrm{F}\right)$ and $1,251 \mathrm{~mm}$ (49.3 in), respectively. In 2012, average temperature and annual precipitation were $12.5^{\circ} \mathrm{C}\left(54.5^{\circ} \mathrm{F}\right)$ and $941 \mathrm{~mm}$ (37 in). The average temperature values in 2011 and 2012 were $7.8 \%$ and $8.6 \%$ higher than that of long-term average temperature, respectively. Annual precipitation in 2011 was $20.4 \%$ higher than that of long-term. The year 2012 was considered as drought year in which the experimental site received $9.4 \%$ less precipitation compared to that of long-term average.

Soil Moisture and Temperature. The daily volumetric moisture content was higher under NT compared to that under CT system (figure 2). Drainage decreased the moisture content under D system compared to that under ND system. Volumetric moisture content was always higher or equal in NT compared to CT system; the highest value of about $45 \mathrm{~m}^{3} \mathrm{~m}^{-3}\left(45 \mathrm{in}^{3} \mathrm{in}^{-3}\right)$ was observed during March through April of 2011 in NT soils. Similarly, soil temperature was also, in general, higher under NT compared to that under CT system (figure 3 ), whereas, it was almost the same under D and ND system (figure 3). Soil temperature peaked (about $40^{\circ} \mathrm{C}\left[104^{\circ} \mathrm{F}\right]$ ) during the summer of 2012 compared to that of 2011 under all the tillage and drainage systems.

Soil Surface Carbon Dioxide Fluxes. Tillage significantly $(p<0.05)$ influenced soil $\mathrm{CO}_{2}$ fluxes for spring of 2011, and spring, summer, and autumn of 2012 (table 3 and figure 4). The soil $\mathrm{CO}_{2}$ fluxes were $36 \%$ higher for CT $\left(31.5 \mathrm{~kg} \mathrm{ha}^{-1} \mathrm{~d}^{-1}\left[28 \mathrm{lb} \mathrm{ac}^{-1}\right.\right.$ 


\section{Figure 1}

Daily precipitation and average daily temperature distribution at the experimental site measured from January 1, 2011, through December 31, 2012.

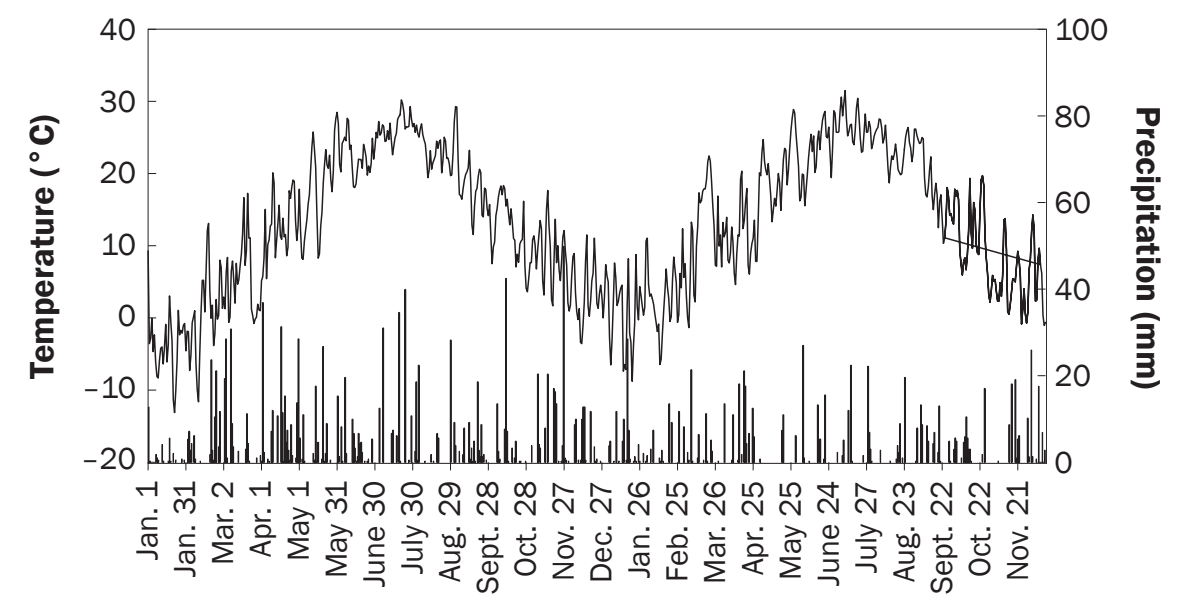

Days

day $\left.\left.^{-1}\right]\right)$ compared to that under NT $(23.2 \mathrm{~kg}$ $\left.\mathrm{ha}^{-1} \mathrm{~d}^{-1}\left[21 \mathrm{lb} \mathrm{ac}^{-1} \mathrm{day}^{-1}\right]\right)$ system for spring of 2011, whereas, it was $2.7 \%$ higher in NT vs. CT for spring of 2012. No-tillage systems increase the fluxes for summer of 2011 (1.3 times) and winter of 2012 (2.1 times) as compared to those of CT, whereas, these fluxes were $62.5 \%$ and $63.1 \%$ higher in CT vs. NT for summer and autumn, respectively, of 2012.

Drainage did not influence soil $\mathrm{CO}_{2}$ fluxes except for autumn 2012 where these fluxes were significantly $(p<0.05)$ higher for ND (18.2 $\left.\mathrm{kg} \mathrm{ha}^{-1} \mathrm{~d}^{-1}\left[16.2 \mathrm{lb} \mathrm{ac}^{-1} \mathrm{day}^{-1}\right]\right)$ as compared to that under D $\left(11 \mathrm{~kg} \mathrm{ha}^{-1} \mathrm{~d}^{-1}[9.8\right.$ $\left.\mathrm{lb} \mathrm{ac} c^{-1} \mathrm{day}^{-1}\right]$ ) system (table 3 and figure 4). The $\mathrm{CO}_{2}$ fluxes were lower for summer as compared to that for spring of 2011 in both drainage systems. Similar trend was observed for 2012. Interactions of tillage by drainage were significant for spring of 2011, and spring, summer, and autumn of 2012.

Soil Surface Nitrous Oxide Fluxes. Results show that tillage significantly $(p<$ 0.05 ) influenced soil $\mathrm{N}_{2} \mathrm{O}$ fluxes for spring seasons of 2011 and 2012 (table 5 and figure 5). The soil $\mathrm{N}_{2} \mathrm{O}$ fluxes were about 5 times higher for CT as compared to that under NT systems for spring of 2011. However, these fluxes were 2.4 times higher for NT vs. CT during spring of 2012 (table 4). Soil $\mathrm{N}_{2} \mathrm{O}$ fluxes peaked in summer of 2012 (figure 5).

Drainage influenced $\mathrm{N}_{2} \mathrm{O}$ fluxes only for spring of 2011 where these fluxes were 2.6 times higher for ND as compared to that under D system. Overall, the soil $\mathrm{N}_{2} \mathrm{O}$ fluxes were lower (in 4 out of 6 seasons; table 4) for D systems compared to ND; however, differences were not significant for all the seasons. Interactions of tillage by drainage were significant only for spring of 2011.

Soil Surface Methane Fluxes. Seasonal data on soil surface $\mathrm{CH}_{4}$ fluxes monitored from soils managed with NT and CT under D and ND systems are shown in table 6 and figure 6. Data show that tillage did not affect $\mathrm{CH}_{4}$ fluxes for any season. However, soil $\mathrm{CH}_{4}$ fluxes were about $11 \%$ and $72 \%$ higher for CT compared to NT system for spring seasons of 2011 and 2012, respectively. However, during the summer of 2011, the $\mathrm{CH}_{4}$ uptake was higher for NT systems compared to that under CT (table 5). Similar trends were observed for autumn and winter of 2012, but in summer uptake of $\mathrm{CH}_{4}$ was higher for CT compared to NT system.

Drainage significantly $(p<0.05)$ influenced $\mathrm{CH}_{4}$ fluxes only for spring of 2012 where fluxes were 7 times higher for ND compared to D system. Soil $\mathrm{CH}_{4}$ fluxes show a general trend for spring seasons (2011 and 2012), revealing about 5.5 and 7.2 times $\mathrm{CH}_{4}$ flux in ND compared to D during spring 2011 and 2012, respectively. Interactions of tillage by drainage were not significant for either year.

Annual Soil Surface Greenhouse Gas Emissions. In 2011, the soil $\mathrm{CO}_{2}$ fluxes were not influenced by either tillage or drainage systems (table 6). However, the annual average of $\mathrm{CO}_{2}$ fluxes was higher for CT (22\%) as compared to that under NT sys- tem. However, ND (6.19 $\mathrm{Mg} \mathrm{ha}^{-1} \mathrm{y}^{-1}[5,525$ $\left.\mathrm{lb} \mathrm{ac}{ }^{-1} \mathrm{yr}^{-1}\right]$ ) decreased the $\mathrm{CO}_{2}$ fluxes compared to that under D $\left(6.36 \mathrm{Mg} \mathrm{ha}^{-1} \mathrm{y}^{-1}[2.6\right.$ $\left.\left.\mathrm{t} \mathrm{ac}^{-1} \mathrm{yr}^{-1}\right]\right)$ system. Interactions of tillage by drainage for $\mathrm{CO}_{2}$ fluxes were nonsignificant for 2011 (table 6). In 2012, tillage significantly influenced the soil $\mathrm{CO}_{2}$ fluxes $(p<$ $0.05)$. The soil $\mathrm{CO}_{2}$ fluxes were $21 \%$ higher for CT $\left(8.37 \mathrm{Mg} \mathrm{ha}^{-1} \mathrm{y}^{-1}\left[3.4 \mathrm{t} \mathrm{ac}^{-1} \mathrm{yr}^{-1}\right]\right)$ as compared to that under NT $\left(6.92 \mathrm{Mg} \mathrm{ha}^{-1}\right.$ $\left.\mathrm{y}^{-1}\left[2.92 \mathrm{t} \mathrm{ac}^{-1} \mathrm{yr}^{-1}\right]\right)$. Results show that drainage did not influence the soil $\mathrm{CO}_{2}$ fluxes. However, interactions of tillage by drainage significantly influenced the $\mathrm{CO}_{2}$ fluxes for 2012 ( $p<0.05$; table 6).

Average annual $\mathrm{N}_{2} \mathrm{O}$ emissions were significantly influenced by tillage and drainage for 2011 and 2012, except that in 2012 these were not significantly influenced by drainage (table 6). The soil $\mathrm{N}_{2} \mathrm{O}$ emissions were 5.9 times higher under CT $\left(2.82 \mathrm{~kg} \mathrm{ha}^{-1} \mathrm{y}^{-1}\right.$ [2.5 $\left.\left.\mathrm{lb} \mathrm{ac}^{-1} \mathrm{yr}^{-1}\right]\right)$ compared to those under NT $\left(0.48 \mathrm{~kg} \mathrm{ha}^{-1} \mathrm{y}^{-1}\left[0.43 \mathrm{lb} \mathrm{ac}^{-1} \mathrm{yr}^{-1}\right]\right)$ systems in 2011. Similarly, these emissions were 1.8 times higher for CT $\left(2.89 \mathrm{~kg} \mathrm{ha}^{-1} \mathrm{y}^{-1}\right.$ [2.57 $\left.\left.\mathrm{lb} \mathrm{ac}^{-1} \mathrm{yr}^{-1}\right]\right)$ systems compared to NT $\left(1.63 \mathrm{~kg} \mathrm{ha}^{-1} \mathrm{y}^{-1}\left[1.45 \mathrm{lb} \mathrm{ac}^{-1} \mathrm{yr}^{-1}\right]\right)$ in 2012. The ND increased the $\mathrm{N}_{2} \mathrm{O}$ emissions by 2.3 and 1.1 times compared to that under D systems in 2011 and 2012, respectively. However, significant differences of $\mathrm{N}_{2} \mathrm{O}$ emissions between ND and D systems were not observed for 2012 (table 6). Interactions of tillage by drainage on $\mathrm{N}_{2} \mathrm{O}$ emissions were nonsignificant for either year.

Average annual emissions of soil $\mathrm{CH}_{4}$ fluxes were nonsignificant for any tillage or drainage systems for either year (table 6). However, these emissions were higher for NT system as compared to that under CT in 2011 and opposite trend was observed in 2012. These emissions were higher for ND system compared to that under D systems for 2011 and 2012 (table 6). Interactions of tillage by drainage on annual average $\mathrm{CH}_{4}$ emissions were nonsignificant.

The GWP was significantly influenced by tillage for either year (table 6). The GWP was $5.92 \mathrm{Mg} \mathrm{ha}^{-1} \mathrm{y}^{-1}\left(2.4 \mathrm{t} \mathrm{ac}^{-1} \mathrm{yr}^{-1}\right)$ for NT system and $7.83 \mathrm{Mg} \mathrm{ha}^{-1} \mathrm{y}^{-1}\left(3.2 \mathrm{t} \mathrm{ac}^{-1} \mathrm{yr}^{-1}\right)$ for CT system for 2011. The GWP for CT $(9.41$ $\left.\mathrm{Mg} \mathrm{ha}^{-1} \mathrm{y}^{-1}\left[3.8 \mathrm{t} \mathrm{ac}^{-1} \mathrm{yr}^{-1}\right]\right)$ systems was $25 \%$ higher as compared to that under NT (7.51 $\left.\mathrm{Mg} \mathrm{ha} \mathrm{y}^{-1} \mathrm{y}^{-1}\left[3 \mathrm{tac}^{-1} \mathrm{yr}^{-1}\right]\right)$ for 2012. Drainage did not influence the GWP. However, interactions of tillage by drainage on GWP were significantly different for either year. 


\section{Figure 2}

Volumetric soil mositure content as influenced by (a) no-tillage and chisel-till and (b) drainage and nondrainage systems under corn-corn cropping rotation.

(a)

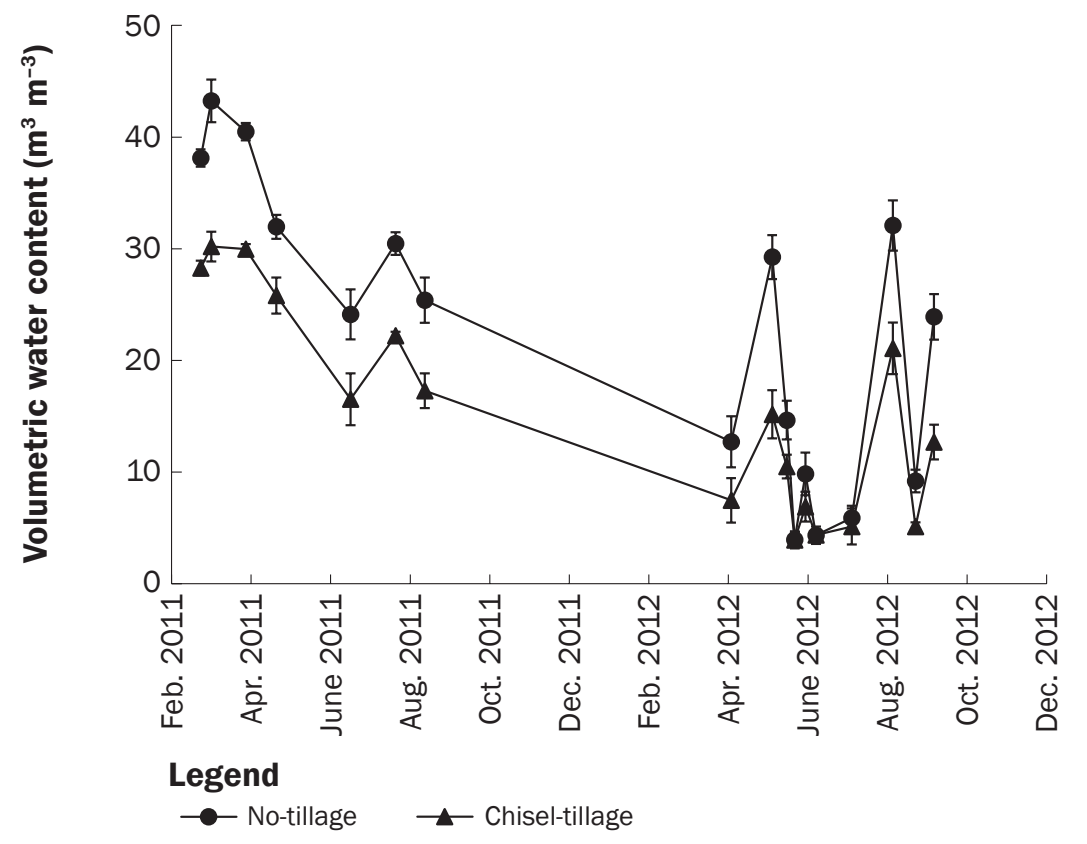

(b)

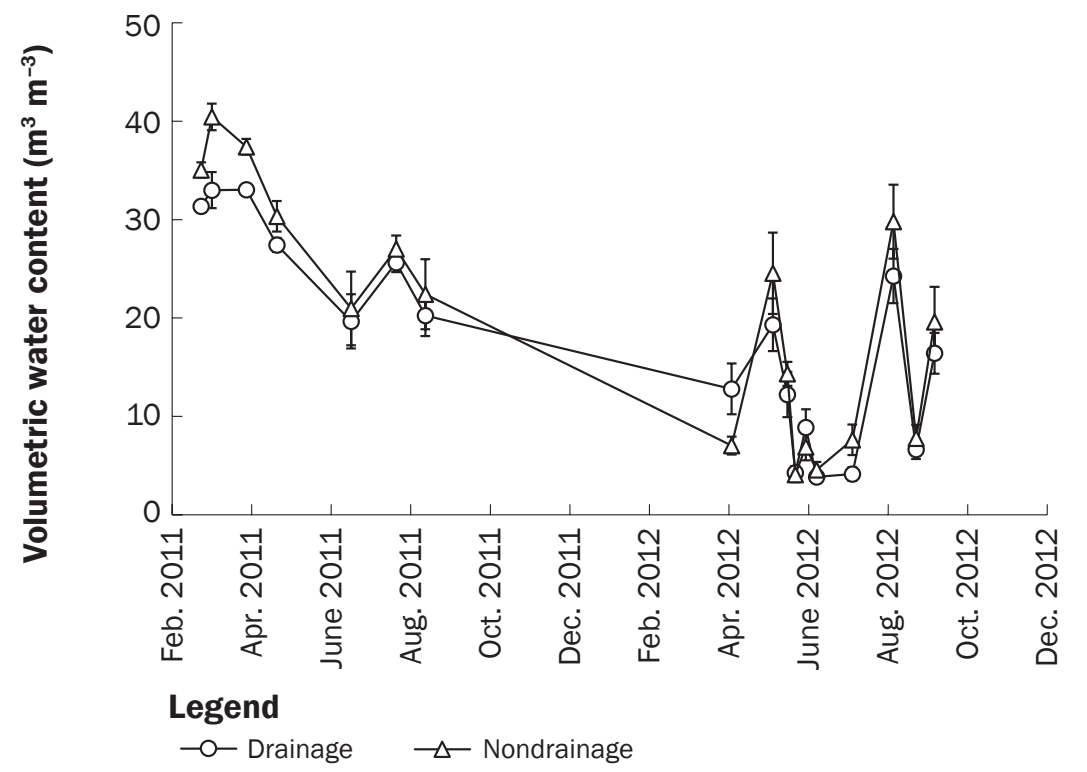

Tillage and Drainage Impacts on Soil Greenhouse Gas Fluxes. Data from this studies show that, in general, soil GHG fluxes were higher for CT system compared to that under NT (table 3, 4, 5; figure 4, 5, 6). This is partially attributed to the fact that tillage operations used in the CT plots disrupted soil structure, increased SOC decomposition, and stimulated higher emissions of gases compared to NT system where no tillage operations were used. Tilling soils affects soil biochemical and physical properties, consequently influencing the release of soil $\mathrm{CO}_{2}$ fluxes (Oorts et al. 2007). This was evident from the SOC data (measured in 2012) which was $4 \%$ higher in the 0 to $10 \mathrm{~cm}$ (0 to 3.93 in) depth for NT soils compared to that for CT.The plots used for the present study were
18 years old, and therefore, it can be suggested that the soils in the NT plots have sequestered more $\mathrm{C}$ compared to that in the $\mathrm{CT}$ plots. The major factors that influence the soil GHG (e.g., $\mathrm{CO}_{2}$ ) fluxes in a tillage system are temperature, moisture, and depth of the tillage practices, with temperature probably being the leading factor (Reicosky et al. 2005). The soils under NT systems are undisturbed, sequester higher SOC, and reduce soil $\mathrm{CO}_{2}$ fluxes. In contrast, tillage breaks up soil aggregates, inhibiting $\mathrm{O}_{2}$ diffusion and hence stimulating denitrification (microbial facilitated process of $\mathrm{NO}_{3}$ reduction) (Patino-Zuniga et al. 2009). Further, a tillage practice that does not go beyond $10 \mathrm{~cm}$ (3.93 in) deeper will lessen the total amount of $\mathrm{CO}_{2}$ lost (Reicosky et al. 2005). Soils under NT systems increase soil organic matter content because of the higher crop residue (Patino-Zuniga et al. 2009). Subsequently, an increase in organic matter in these systems will cause more aeration in the surface 0 to $15 \mathrm{~cm}$ (0 to 5.91 in) depth which in turn reduces denitrification as compared to that under tilled systems (Patino-Zuniga et al. 2009). The NT systems restore soil C levels through the retention and incorporation of crop residues, and the reduction in high-disturbance cultivation subsequently reduces overall GHG emissions through a reduction in farm machinery operations.

Soil moisture content strongly affects the $\mathrm{N}_{2} \mathrm{O}$ fluxes. Soil surface $\mathrm{N}_{2} \mathrm{O}$ fluxes in spring of 2011, and spring, summer, autumn, and winter of 2012 were lower in NT compared to those of CT. This could partially be attributed to the fact that any $\mathrm{N}_{2} \mathrm{O}$ produced in the soil may have been converted to $\mathrm{N}_{2}$ due to the high moisture content in NT system (figure 2) and hence there would be very little $\mathrm{N}_{2} \mathrm{O}$ escaped to the atmosphere. Similar finding were also reported by Venterea et al. (2008).

Tillage impacts on soil GHG fluxes are mixed and strongly depend on duration of tillage, soil types, and climate. For example, MacKenzie et al.(1998) reported increased $\mathrm{N}_{2} \mathrm{O}$ emissions following reduced or NT management on fine-textured soils including clay, silty clay loam, imperfectly drained clay loam (Ball et al. 1999), and silt loam (Baggs et al. 2003). Increased $\mathrm{N}_{2} \mathrm{O}$ emissions rates in these situations were attributed to availability of more plant materials, which are sources of $\mathrm{C}$ and energy for heterotrophic denitrifying organisms (Dalal et al. 2003; Iqbal 1992). In contrast, Grandy and Robertson (2006) 


\section{Figure 3}

Soil temperature for the o to $5 \mathrm{~cm}$ depth as influenced by (a) no-tillage and chisel-till and (b) drainage and nondrainage systems under corn-corn cropping rotation.

(a)

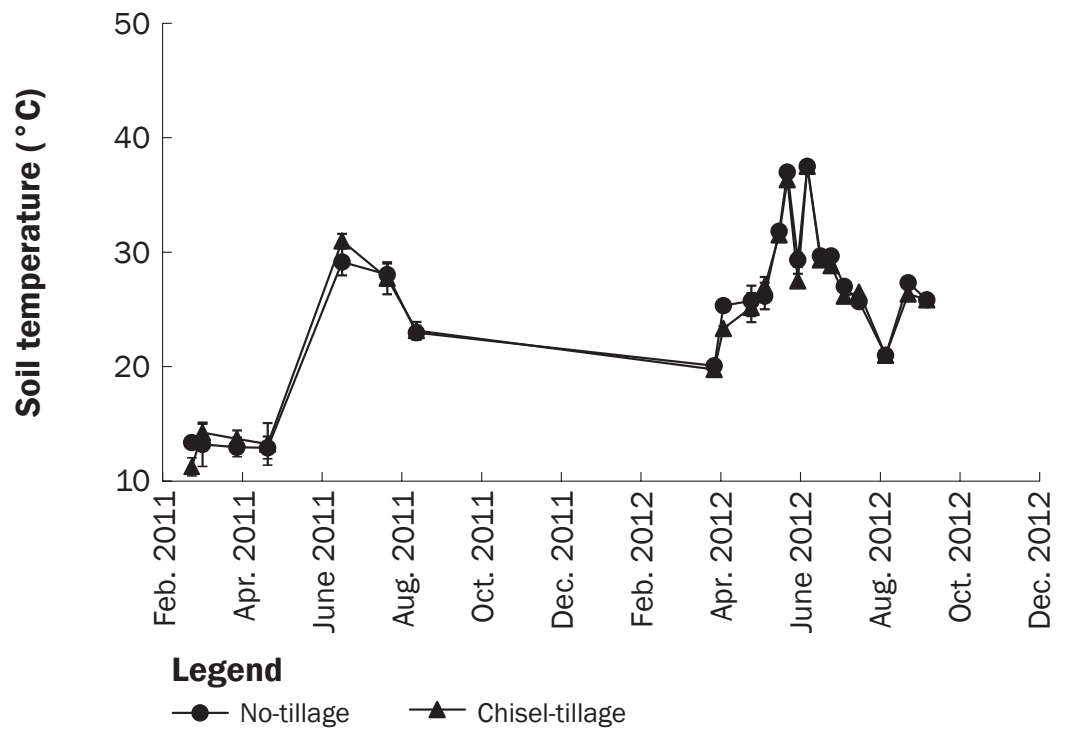

(b)

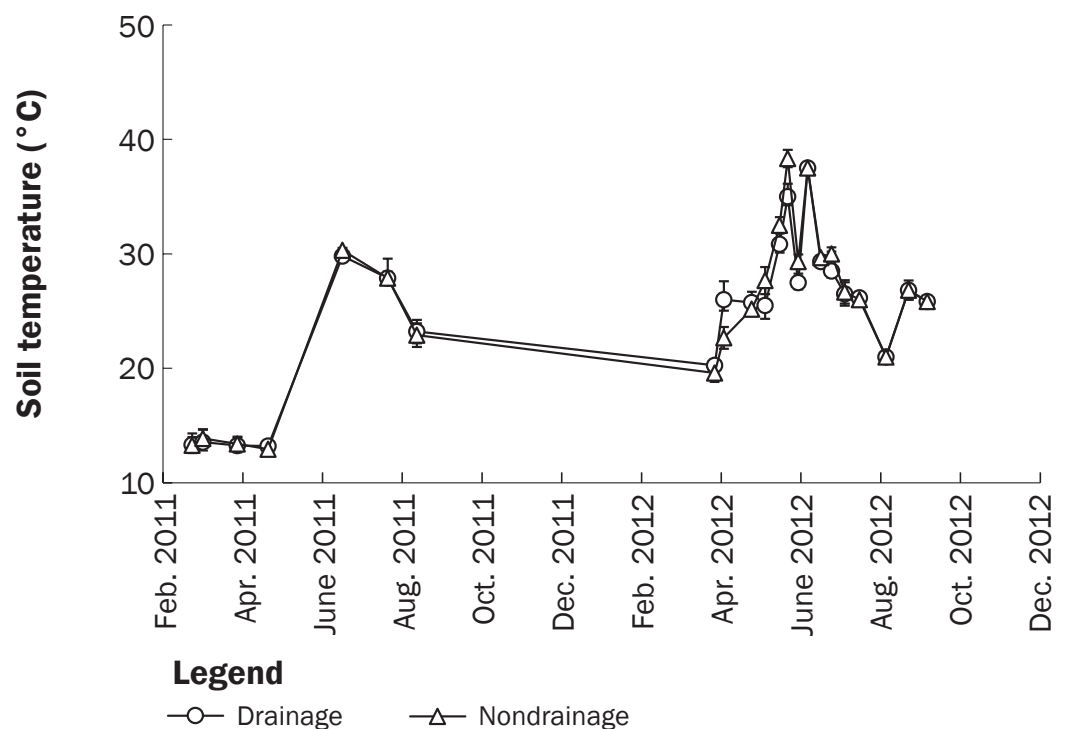

showed no differences in flux due to tillage on fine/coarse-loamy soils. Results from the present study showed that soil GHG emissions are influenced by tillage and drainage, however, these fluxes respond differently in every season. Therefore, it is recommended that monitoring of these soil GHGs should be conducted for longer duration, and under different environmental conditions for better conclusions. Some researchers reported that NT is effective in reducing SOC losses but not in increasing the total C stock, primarily because of warmer winters that are likely to increase the rate of SOC mineralization (Chan et al. 2003). In some situations, NT practice enhances weed population and growth, and large amount of herbicides, which have high global warming potential compared to other agrochemicals are needed (Lal 2004). Therefore, crop rotations and cover crops are encouraged to overcome weed growth. This study used a corn-corn rotation under poorly drained soils which may behave differently when using cornsoybean (Glycine max L.) rotation or other diversified cropping system, and this could be a future researchable question under poorly drained soils.

Soil GHG emissions are spatially and temporally variable. These fluxes for the present study were different in both 2011 and 2012 years, and these differences were attributed to the fact that 2011 was wet compared to 2012, which was a drought year (figure 1). The precipitation in 2011 was 33\% higher compared to that in 2012. Data collected from this study show that, on an average, the annual soil GHG emissions were higher for 2012 compared to those of 2011. This could also partially be attributed to the differences in air temperature and precipitation for both years.

It has been well documented that drainage significantly influences the mineralization and denitrification processes. The soil $\mathrm{N}_{2} \mathrm{O}$ fluxes for this study, in general, were higher for ND compared to that under D management. Poor drainage under CT or NT plots enhances the denitrification, and thereby increases soil $\mathrm{N}_{2} \mathrm{O}$ fluxes. Drainage impacts on soil $\mathrm{N}_{2} \mathrm{O}$ fluxes in both tillage systems for the present study were obvious. Venterea et al. (2008) observed that tile-drained systems impact soil $\mathrm{N}_{2} \mathrm{O}$ fluxes by impacting the moisture content of the soils. These researchers concluded that higher moisture levels in the nondrained soil contributed to a higher denitrification and $\mathrm{N}_{2} \mathrm{O}$ production. However, one section of their fields, which was the most poorly drained, had the least amount of $\mathrm{N}_{2} \mathrm{O}$ fluxes. They concluded that this was most likely due to the very high moisture content in the soil which in turn may have inhibited nitrification and $\mathrm{NO}_{3}$ production. In the present study, in general, soil $\mathrm{N}_{2} \mathrm{O}$ fluxes were higher in $\mathrm{ND}$ vs. $\mathrm{D}$ in 2011 and 2012 (table 4), which was due to higher moisture content (figure 2).

Soil $\mathrm{CO}_{2}$ fluxes from NT system were lower in spring of 2011 and autumn of 2012 compared to that from CT, and higher in spring, summer, and winter of 2012 (table 3). The production of $\mathrm{CO}_{2}$ in the soil is generally higher in aerobic soil conditions as compared to anaerobic conditions (Lal et al. 1995). There are many biological processes that impact the rate and production of $\mathrm{CO}_{2}$ in the soil including microbial activity on soil organic matter, root respiration, and moisture content in the soil. Increased aeration in the soil alters soil microbial population ,which increases oxidation of organic matter and increases $\mathrm{CO}_{2}$ emission after drainage (Freeman et al. 1992). Lal et al. (1995) stated 
Table 3

Seasonal mean carbon dioxide ( $\left.\mathrm{CO}_{2}\left[\mathrm{~kg} \mathrm{ha}^{-1} \mathrm{~d}^{-1}\right]\right)$ fluxes from soils managed with no-till (NT) and chisel-till (CT) under drainage (D) and nondrainage (ND) systems of corn-corn cropping rotation in an alfisol of Ohio.

\begin{tabular}{|c|c|c|c|c|c|c|}
\hline \multirow[b]{2}{*}{ Treatments } & \multicolumn{2}{|c|}{ Season 2011} & \multicolumn{4}{|c|}{ Season 2012} \\
\hline & Spring & Summer & Spring & Summer & Autumn & Winter \\
\hline NT & $23.2 b *$ & $15.2 a$ & $36.7 b$ & $22.4 b$ & $11.1 b$ & $2.9 a$ \\
\hline СТ & $31.5 a$ & $12.0 \mathrm{a}$ & $37.7 a$ & $36.4 a$ & $18.1 a$ & $1.4 a$ \\
\hline D & $27.8 a$ & $13.3 a$ & $36.5 a$ & $29.0 a$ & $11.0 \mathrm{~b}$ & $1.9 a$ \\
\hline \multirow[t]{2}{*}{ ND } & $26.8 a$ & $13.9 a$ & $35.9 a$ & $29.7 a$ & $18.2 a$ & $2.4 a$ \\
\hline & \multicolumn{6}{|c|}{ Analysis of variance $p>f$} \\
\hline Tillage & 0.023 & 0.234 & 0.033 & $<0.001$ & 0.004 & 0.065 \\
\hline Drainage & 0.706 & 0.794 & 0.647 & 0.747 & 0.004 & 0.533 \\
\hline Tillage $\times$ drainage & 0.028 & 0.963 & $<0.001$ & 0.047 & 0.007 & 0.979 \\
\hline
\end{tabular}

* Means followed by different letters within a column, and treatment are significantly different at $p<0.05$.

\section{Figure 4}

Soil carbon dioxide ( $\left.\mathrm{CO}_{2}\right)$ fluxes as influenced by (a) no-tillage and chisel-till and (b) drainage and nondrainage systems under corn-corn cropping rotation.

(a)

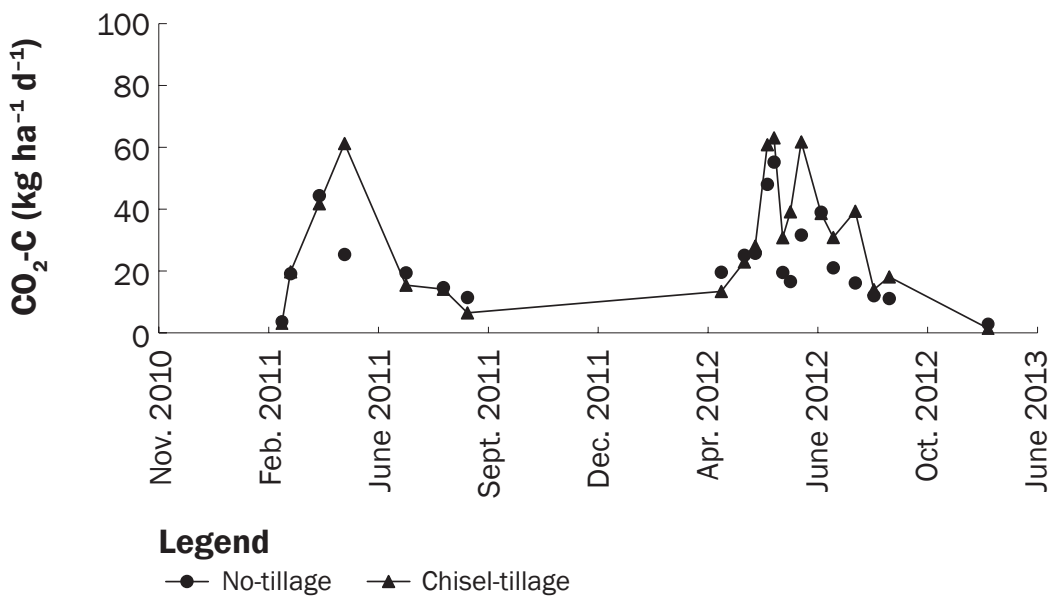

(b)

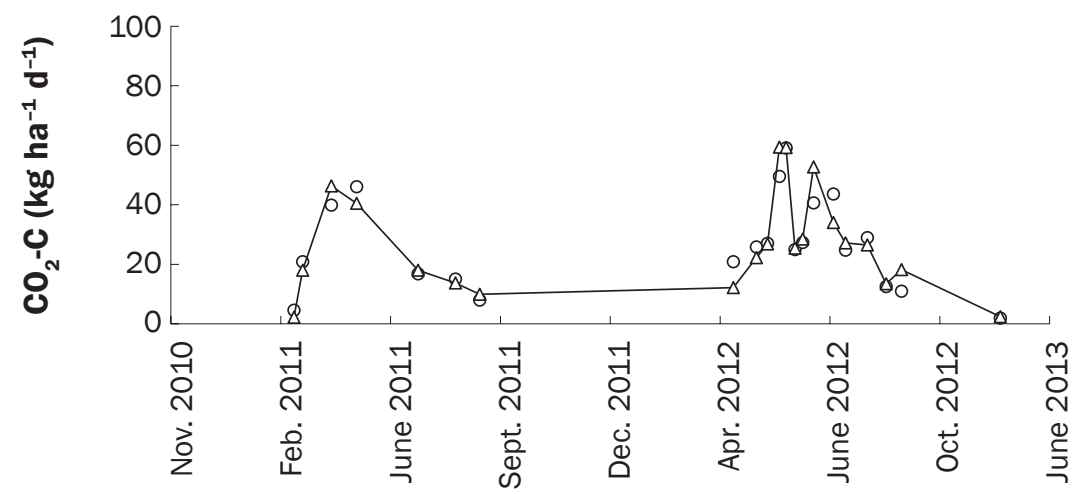

Legend

$\rightarrow-$ Drainage $\rightarrow$ Nondrainage that by increasing soil wetness past wilting point and about slightly over half $(60 \%$ to $80 \%$ ) of saturation point, the amount of $\mathrm{CO}_{2}$ produced is increased. In this study, moisture content in CT soils was always less than about $30 \%$ which favored the $\mathrm{CO}_{2}$ production. Soil moisture content in NT soils was generally higher compared to CT, except during summer of 2012 where it was almost the same between both the tillage systems (figure 2). Further, soil moisture in NT soils was close to saturation (figure 2) which created anaerobic conditions and favored the denitrification, hence enhanced the $\mathrm{N}_{2} \mathrm{O}$ fluxes.

The rates of $\mathrm{CH}_{4}$ flux in the soil are influenced by many constantly changing variables, including temperature, soil class, moisture, crops planted, fertilizer rates, and management techniques. The $\mathrm{CH}_{4}$ production is favored in soils with high amounts of organic matter and moisture content. High fluxes of $\mathrm{CH}_{4}$ have been recorded in poorly drained soils due to the high moisture content and limited amount of oxygen $\left(\mathrm{O}_{2}\right)$ in soil pores. Soil $\mathrm{CH}_{4}$ fluxes from both tillage systems were almost the same for either years; however, nondrainage increased $\mathrm{CH}_{4}$ fluxes by 5.5 and 7.2 times for spring seasons of 2011 and 2012, respectively (table 5). High moisture content in ND system favors $\mathrm{CH}_{4}$ production (figure 2) but limits $\mathrm{CH}_{4}$ oxidation (Hyvönen et al. 2013). Soil $\mathrm{CH}_{4}$ fluxes are highly spatially and temporally variable and as reported in the previous studies. There are other factors that affect $\mathrm{CH}_{4}$ emissions and some of them include water table depth, air and soil water temperatures, availability and quality of substrates, and vegetation characteristics (Whalen 2005). Therefore, further research needed that will involve measuring different biogeochemical processes involved in $\mathrm{CH}_{4}$ production and oxidation.

The interactions of tillage by drainage had some significant influences on soil GHG fluxes measured in this study (table 3, 4, and 6). Soils managed with NT system improved SOC concentrations (0 to $10 \mathrm{~cm}$ [0 to 3.94 in] depth) for the present study and reduced soil BD. However, these SOC measurements were conducted in 2012 and further investigation is needed that can report SOC change with time over the start of the experiment. Subsurface drainage improves soil aeration and decreases denitrification. In contrast, higher moisture content creates anaerobic conditions and enhances the denitrification, hence the $\mathrm{N}_{2} \mathrm{O}$ fluxes. This was observed for 
Table 4

Seasonal nitrous oxide $\left(\mathrm{N}_{2} \mathrm{O}\left[\mathrm{g} \mathrm{ha}^{-1} \mathrm{~d}^{-1}\right]\right)$ fluxes from soils managed with no-tillage (NT) and chisel-till (CT) under drainage (D) and nondrainage (ND) systems of corn-corn cropping rotation in an alfisol of Ohio.

\begin{tabular}{|c|c|c|c|c|c|c|}
\hline \multirow[b]{2}{*}{ Treatment } & \multicolumn{2}{|c|}{ Season 2011} & \multicolumn{4}{|c|}{ Season 2012} \\
\hline & Spring & Summer & Spring & Summer & Autumn & Winter \\
\hline NT & $2.72 b *$ & $0.86 a$ & $11.50 \mathrm{~b}$ & $2.40 a$ & $0.50 a$ & $3.46 a$ \\
\hline CT & 13.39a & $0.43 a$ & $27.20 a$ & $4.31 a$ & $2.93 a$ & $-0.88 a$ \\
\hline D & $4.50 \mathrm{~b}$ & $0.51 a$ & $19.97 a$ & $2.51 a$ & $2.43 a$ & $0.06 a$ \\
\hline \multirow[t]{2}{*}{ ND } & $11.60 a$ & $0.78 a$ & $18.28 a$ & $5.14 a$ & $1.00 a$ & $2.52 a$ \\
\hline & \multicolumn{6}{|c|}{ Analysis of variance $p>f$} \\
\hline Tillage & 0.018 & 0.670 & 0.003 & 0.694 & 0.418 & 0.331 \\
\hline Drainage & 0.003 & 0.792 & 0.639 & 0.300 & 0.633 & 0.573 \\
\hline Tillage $\times$ drainage & 0.050 & 0.718 & 0.712 & 0.917 & 0.579 & 0.499 \\
\hline
\end{tabular}

* Means followed by different letters within a column, and treatment are significantly different at $p<0.05$.

\section{Figure 5}

Soil nitrous oxide $\left(\mathrm{N}_{2} \mathrm{O}\right)$ fluxes as influenced by (a) no-tillage and chisel-till and (b) drainage and systems under corn-corn cropping rotation.

(a)

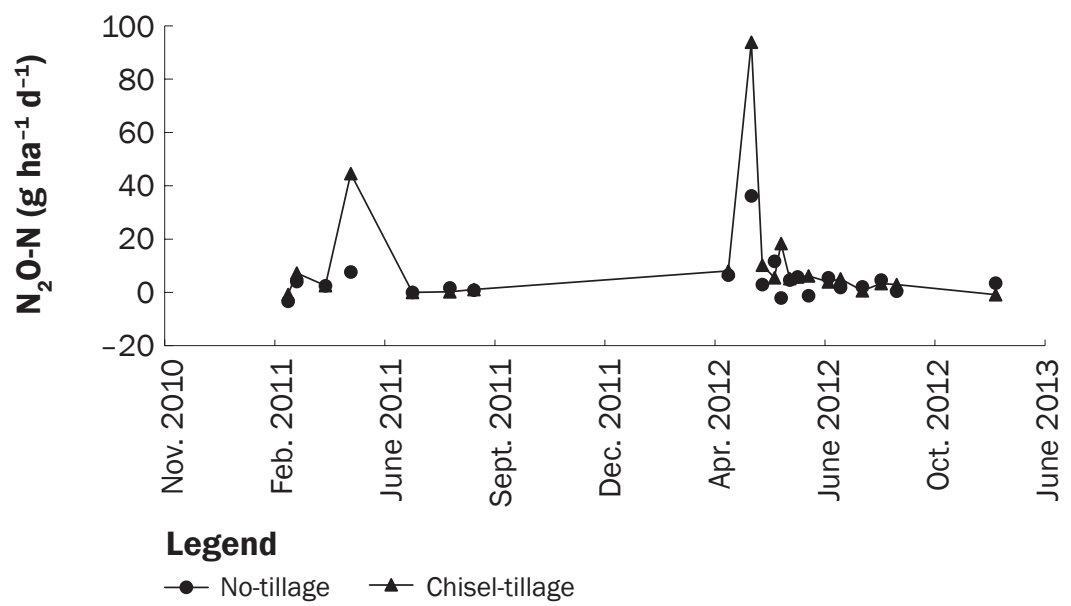

(b)

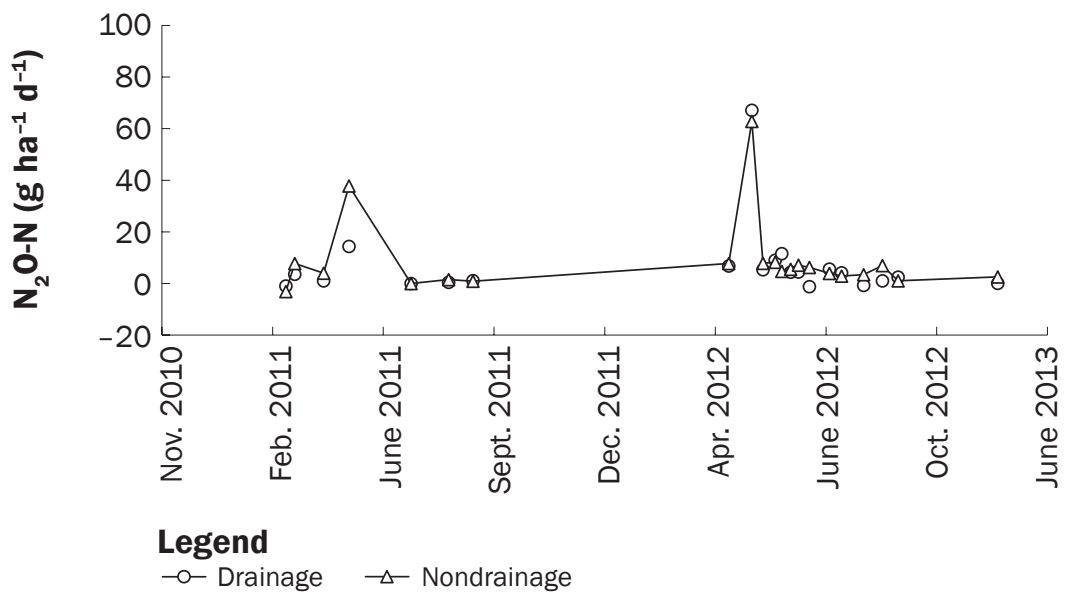

the present study. However, a very limited research has been conducted on drainage impacts on GHG fluxes under poorly drained soils.

Research Gaps. Profound research related to long-term impacts of tillage and drainage on soil GHG fluxes under poorly drained soils is still lacking. These poorly drained soils create anaerobic conditions, which affect biogeochemical cycling of $\mathrm{C}$ and $\mathrm{N}$, thereby impacting the exchange of GHG fluxes between the ecosystem and atmosphere (Laine et al. 1996). These fluxes can be mitigated if poorly drained soils are managed with subsurface drainage systems, and using diverse cropping systems to improve aeration and control weed problem. However, these GHG fluxes need to be monitored for longer duration under diverse environmental conditions. This study was conducted under corn-corn rotation; however, future research can be conducted on situations that focus on use of cover crops under diverse crop rotations in poorly drained soils. Since GHG fluxes are spatially and temporally variable, modeling these fluxes using process-based models could be a possible solution to explore strategies for mitigating these fluxes from soils that are poorly drained. Further, short term studies are unconvincing because of larger variability in soil and climate during the crop growing season; hence emphasis on long-term studies is encouraged.

\section{Summary and Conclusions}

The present study assesses the long-term tillage and drainage influences on soil GHG fluxes. The latter were monitored for a 2 -year period (2011 and 2012) from corn-corn rotation under poorly drained soil of central Ohio. Results show that SOC concentrations (measured in 2012) for the surface 0 to $10 \mathrm{~cm}$ (0 to $3.94 \mathrm{in}$ ) depth was 4\% higher under NT compared to that under CT plots. Data show that the seasonal $\mathrm{CO}_{2}$ fluxes were influenced by tillage in spring of 2011, and spring, summer, and autumn of 2012. The soil $\mathrm{N}_{2} \mathrm{O}$ fluxes were also influenced by tillage for spring of 2011 and 2012 only. The annual average of soil $\mathrm{CO}_{2}$ fluxes was significantly higher for $\mathrm{CT}$ as compared to that under NT system in 2012. Average annual $\mathrm{N}_{2} \mathrm{O}$ emissions were significantly influenced by tillage and drainage for 2011 and 2012, except that in 2012 these were not significantly influenced by drainage due to less precipitation. The soil $\mathrm{N}_{2} \mathrm{O}$ emissions were 
Table 5

Seasonal mean methane $\left(\mathrm{CH}_{4}\left[\mathrm{~g} \mathrm{ha}^{-1} \mathrm{~d}^{-1}\right]\right)$ fluxes from soils managed with no-till (NT) and chisel-till (CT) under drainage (D) and nondrainage (ND) systems of corn-corn cropping rotation in an alfisol of Ohio.

\begin{tabular}{|c|c|c|c|c|c|c|}
\hline \multirow[b]{2}{*}{ Treatment } & \multicolumn{2}{|c|}{ Season 2011} & \multicolumn{4}{|c|}{ Season 2012} \\
\hline & Spring & Summer & Spring & Summer & Autumn & Winter \\
\hline NT & $17.82 a *$ & $-13.81 a$ & $16.78 a$ & $7.38 a$ & $-9.49 a$ & $-8.23 a$ \\
\hline CT & $19.73 a$ & $-3.87 a$ & $28.82 a$ & $-5.02 a$ & $7.08 a$ & $6.22 a$ \\
\hline D & $5.80 a$ & $-11.28 a$ & $5.06 \mathrm{~b}$ & $5.07 a$ & $-5.00 a$ & $-10.47 a$ \\
\hline \multirow[t]{2}{*}{ ND } & $31.75 a$ & $-6.40 a$ & $36.63 a$ & $-9.81 a$ & $2.59 a$ & $8.46 a$ \\
\hline & \multicolumn{6}{|c|}{ Analysis of variance $p>f$} \\
\hline Tillage & 0.949 & 0.731 & 0.212 & 0.684 & 0.205 & 0.452 \\
\hline Drainage & 0.402 & 0.866 & 0.032 & 0.278 & 0.509 & 0.336 \\
\hline Tillage $\times$ drainage & 0.214 & 0.505 & 0.239 & 0.750 & 0.920 & 0.404 \\
\hline
\end{tabular}

* Means followed by different letters within a column, and treatment are significantly different at $p<0.05$.

\section{Figure 6}

Soil methane $\left(\mathrm{CH}_{4}\right)$ fluxes as influenced by (a) no-tillage and chisel-till and (b) drainage and systems under corn-corn cropping rotation.

(a)

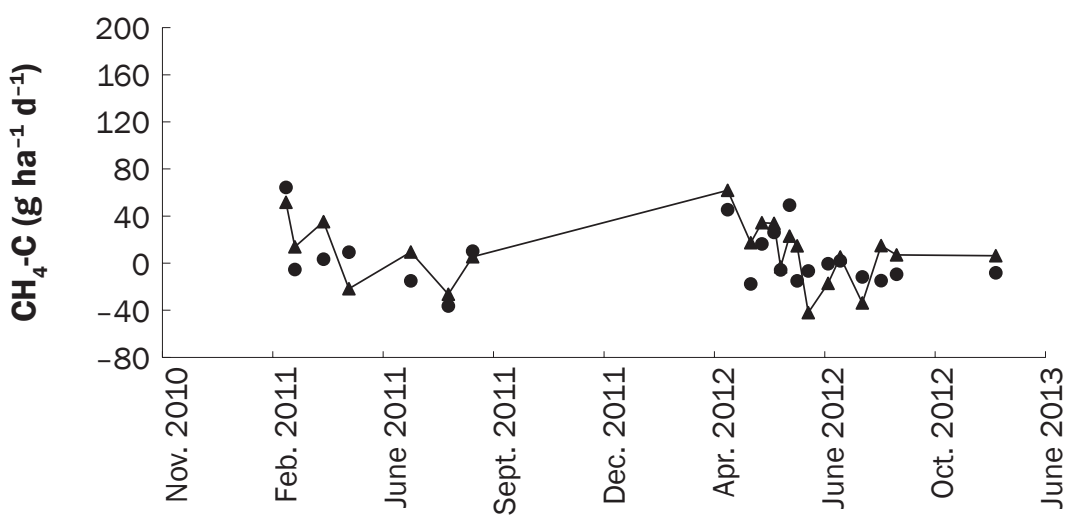

\section{Legend}

$\rightarrow$ No-tillage $\rightarrow$ Chisel-tillage

(b)

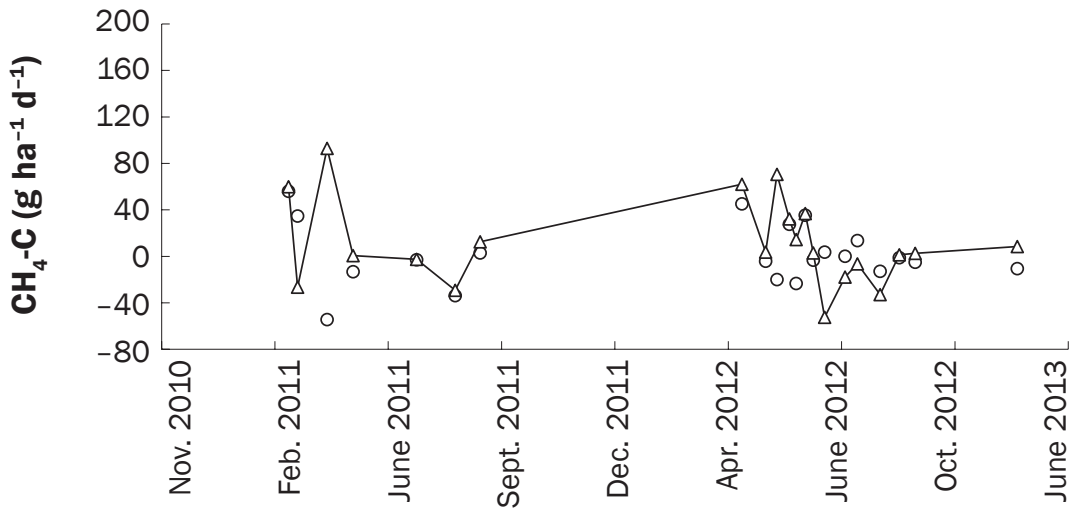

Legend

$\multimap$ Drainage $\rightarrow$ Nondrainage
5.9 times higher under CT $\left(2.82 \mathrm{~kg} \mathrm{ha}^{-1} \mathrm{y}^{-1}\right.$ [2.5 $\left.\left.\mathrm{lb} \mathrm{ac}^{-1} \mathrm{yr}^{-1}\right]\right)$ compared to those under NT $\left(0.48 \mathrm{~kg} \mathrm{ha}^{-1} \mathrm{y}^{-1}\left[0.43 \mathrm{lb} \mathrm{ac}^{-1} \mathrm{yr}^{-1}\right]\right)$ systems in 2011. Similarly, these emissions were 1.8 times higher for CT $\left(2.89 \mathrm{~kg} \mathrm{ha}^{-1} \mathrm{y}^{-1}\right.$ [2.58 $\left.\mathrm{lb} \mathrm{ac}^{-1} \mathrm{yr}^{-1}\right]$ ) systems compared to NT $\left(1.63 \mathrm{~kg} \mathrm{ha}^{-1} \mathrm{y}^{-1}\left[1.45 \mathrm{lb} \mathrm{ac}^{-1} \mathrm{yr}^{-1}\right]\right)$ in 2012. The ND increased the $\mathrm{N}_{2} \mathrm{O}$ emissions by 2.5 times compared to that under $\mathrm{D}$ systems in 2011. Average annual emissions of soil $\mathrm{CH}_{4}$ were nonsignificant for any tillage or drainage systems. In general, soils under $\mathrm{CT}$ with nondrainage systems increased the soil GHG emissions; however, significant differences were not always observed.

It can be concluded from this study that long-term NT practice combined with subsurface tile drainage can be beneficial for the environment by emitting less GHG fluxes to the atmosphere. However, long-term monitoring of these fluxes under different crop rotations is needed because of seasonal fluctuations in the climate.

\section{References}

Arah, J., K. Smith, I. Crichton, and H. Li. 1991. Nitrous oxide production and denitrification in Scottish arable soils. Journal of Soil Science 42(3):351-367.

Baggs, E.M., M. Stevenson, M. Pihlatie, A. Regar, H. Cook, and G. Cadisch. 2003. Nitrous oxide emissions following application of residues and fertiliser under zero and conventional tillage. Plant and Soil 254(2):361-370.

Ball, B.C., A. Scott, and J.P. Parker. 1999. Field $\mathrm{N}_{2} \mathrm{O}, \mathrm{CO}_{2}$ and $\mathrm{CH}_{4}$ fluxes in relation to tillage, compaction and soil quality in Scotland. Soil and Tillage Research 53(1):29-39.

Cannell, R.Q., R.K. Belford, P.S. Blackwell, G. Govi, and R.J. Thomson. 1985. Effects of waterlogging on soil aeration and on root and shoot growth and yield of winter oats (Avena-sativa L). Plant and Soil 85(3):361-373.

Chan, K.Y., D.P. Heenan, and H.B. So. 2003. Sequestration of carbon and changes in soil quality under conservation tillage on light-textured soils in Australia: A review. Australian Journal of Experimental Agriculture 43(4):325-334.

Cole, C.V., J. Duxbury, J. Freney, O. Heinemeyer, K. Minami, A. Mosier, K. Paustian, N. Rosenberg, N. Sampson, D. Sauerbeck, and Q. Zhao. 1997. Global estimates of potential mitigation of greenhouse gas emissions by agriculture. Nutrient Cycling in Agroecosystems 49(1-3):221-228.

Dalal, R.C., W.J.Wang, G.P. Robertson, and W.J. Parton. 2003. Nitrous oxide emission from Australian agricultural lands and mitigation options: A review. Australian Journal of Soil Research 41(2):165-195. 


\section{Table 6}

Annual carbon dioxide $\left(\mathrm{CO}_{2}\right)$ nitrous oxide $\left(\mathrm{N}_{2} \mathrm{O}\right)$ and methane $\left(\mathrm{CH}_{4}\right)$ fluxes from soils managed with no-tillage (NT) and chisel-till (CT) under drainage (D) and nondrainage (ND) systems of corn-corn cropping rotation in an alfisol of Ohio, and their global warming potential (GWP) for 2011 and 2012.

\begin{tabular}{|c|c|c|c|c|}
\hline Treatment & $\begin{array}{l}\mathrm{CO}_{2} \\
\left(\mathrm{Mg} \mathrm{ha}^{-1} \mathrm{y}^{-1}\right)\end{array}$ & $\begin{array}{l}N_{2} \mathrm{O} \\
\left(\mathrm{kg} \mathrm{ha}^{-1} \mathrm{y}^{-1}\right)\end{array}$ & $\begin{array}{l}\mathrm{CH}_{4} \\
\left(\mathrm{~kg} \mathrm{ha}^{-1} \mathrm{y}^{-1}\right)\end{array}$ & $\begin{array}{l}\text { GWP } \\
\left(M^{\prime} h^{-1} y^{-1}\right)\end{array}$ \\
\hline \multicolumn{5}{|l|}{2011} \\
\hline NT & $5.66 a *$ & $0.48 b$ & $5.37 a$ & $5.92 b$ \\
\hline CT & $6.90 a$ & $2.82 a$ & $4.36 a$ & $7.83 a$ \\
\hline $\mathrm{D}$ & $6.36 a$ & $0.99 b$ & $2.76 a$ & $6.72 \mathrm{a}$ \\
\hline \multirow[t]{2}{*}{ ND } & $6.19 a$ & $2.31 a$ & $6.97 a$ & $7.04 a$ \\
\hline & \multicolumn{4}{|c|}{ Analysis of variance $p>f$} \\
\hline Tillage & 0.101 & 0.016 & 0.881 & 0.006 \\
\hline Drainage & 0.803 & 0.041 & 0.541 & 0.514 \\
\hline Tillage $\times$ Drainage & 0.136 & 0.244 & 0.354 & 0.017 \\
\hline \multicolumn{5}{|l|}{2012} \\
\hline NT & $6.92 b$ & $1.63 b$ & $4.42 a$ & $7.51 b$ \\
\hline CT & $8.37 a$ & $2.89 a$ & $8.26 a$ & $9.41 a$ \\
\hline D & $7.77 a$ & $2.14 a$ & $4.99 a$ & $8.52 a$ \\
\hline \multirow[t]{2}{*}{ ND } & $7.52 \mathrm{a}$ & $2.38 a$ & $7.68 a$ & $8.40 a$ \\
\hline & \multicolumn{4}{|c|}{ Analysis of variance $p>f$} \\
\hline Tillage & 0.003 & 0.027 & 0.264 & $<0.001$ \\
\hline Drainage & 0.435 & 0.696 & 0.420 & 0.713 \\
\hline Tillage $\times$ drainage & 0.013 & 0.630 & 0.659 & 0.018 \\
\hline
\end{tabular}

* Means followed by different letters within a column, and treatment are significantly different at $p<0.05$.

Drury, C., W. Findlay, J. Gaynor, and D. McKenney. 1993. Influence of tillage on nitrate loss in surface runoff and tile drainage. Soil Science Society of America Journal 57(3):797-802.

Freeman, C., M. Lock, and B. Reynolds. 1992. Fluxes of $\mathrm{CO}_{2}, \mathrm{CH}_{4}$ and $\mathrm{N}_{2} \mathrm{O}$ from a Welsh peatland following simulation of water table draw-down: potential feedback to climatic change. Biogeochemistry 19(1):51-60.

Grandy, A.S., and G.P. Robertson. 2006. Initial cultivation of a temperate-region soil immediately accelerates aggregate turnover and $\mathrm{CO}_{2}$ and $\mathrm{N}_{2} \mathrm{O}$ fluxes. Global Change Biology 12(8):1507-1520.

Gregorich, E.G., P. Rochette, A.J. VandenBygaart, and D.A. Angers. 2005. Greenhouse gas contributions of agricultural soils and potential mitigation practices in Eastern Canada. Soil and Tillage Research 83(1):53-72.

Grossman, R.B., and T.G. Reinsch. 2002. Bulk density and linear extensibility. In Methods of Soil Analysis, Part 4, eds. J.H. Danem G.C. Topp, 201-225. Madison, WI: Soil Science Society of America

Hill, A.R., and M. Cardaci. 2004. Denitrification and organic carbon availability in riparian wetland soils and subsurface sediments. Soil Science Society of America Journal 68(1):320-325.

Hyvönen, N., J.T. Huttunen, N.J. Shurpali, S.E. Lind, M.E. Marushchak, L. Heitto, and P. Martikainen. 2013. The role of drainage ditches in greenhouse gas emissions and surface leaching losses from a cutaway peatland cultivated with a perennial bioenergy crop. Boreal Environment Research 18(2):109-126.

IPCC (Intergovernmental Panel on Climate Change). 2001a. Climate Change 2001: Impacts, adaptation and vulnerability. Cambridge, UK: Cambridge University Press. IPCC (Intergovernmental Panel on Climate Change). 2001b. Climate change 2001: The scientific basis. Contribution of Working Group 1 to the Third Assessment Report of the Intergovernmental Panel on Climate Change. Cambridge University Press, Cambridge, UK

Iqbal, M.M. 1992. Potential rates of denitrification in 2 field soils in southern England. Journal of Agricultural Science 118:223-227.

Jacinthe, P.A., and W.A. Dick. 1997. Soil management and nitrous oxide emissions from cultivated fields in southern Ohio. Soil and Tillage Research 41(3-4):221-235.

Kumar, S., A. Kadono, R. Lal, and W.A. Dick. 2012. Longterm no-till impacts on organic carbon and properties of two contrasting soils and corn yields in Ohio. Soil Science Society of America Journal 76(5):1798-1809.

Laine, J., J. Silvola, K. Tolonen, J. Alm, H. Nykänen, H. Vasander, T. Sallantaus, I. Savolainen, J. Sinisalo, and P.J. Martikainen. 1996. Effect of water-level drawdown on global climatic warming: Northern peatlands. Ambio:179-184.

Lal, R. 2004. Soil carbon sequestration impacts on global climate change and food security. Science 304(5677):1623-1627.
Lal, R., J. Kimble, E. Levine, and B.A. Stewart. 1995. Soil Management and Greenhouse Effect. Chelsea, MI: Lewis Publishers.

Lal, R., and G.S. Taylor. 1970. Drainage and nutrient effects in a field lysimeter study.II. Mineral uptake by corn. Soil Science Society of America Proceedings 34(2):245-248.

Lee, J., J. Six, A.P. King, C. Van Kessel, and D.E. Rolston. 2006. Tillage and field scale controls on greenhouse gas emissions. Journal of Environmental Quality 35(3):714-725

Linquist, B.A., M.A. Adviento-Borbe, C.M Pittelkow, C. van Kessel, and K.J. van Groenigen. 2012. Fertilizer management practices and greenhouse gas emissions from rice systems: A quantitative review and analysis. Field Crops Research 135:10-21.

MacKenzie, A.F., M.X. Fan, and F. Cadrin. 1998. Nitrous oxide emission in three years as affected by tillage, cornsoybean-alfalfa rotations, and nitrogen fertilization. Journal of Environmental Quality 27(3):698-703.

Maraseni, T.N., and G. Cockfield. 2011. Does the adoption of zero tillage reduce greenhouse gas emissions? An assessment for the grains industry in Australia. Agricultural Systems 104(6):451-458.

McConkey, B.G., B.C. Liang, C.A. Campbell, D. Curtin, A. Moulin, S.A. Brandt, and G.P. Lafond. 2003. Crop rotation and tillage impact on carbon sequestration in Canadian prairie soils. Soil and Tillage Research 74(1):81-90

Mehnert, E., H.H. Hwang, T.M. Johnson, R.A. Sanford, W.C. Beaumont, and T.R. Holm. 2007. Denitrification in the Shallow Ground Water of a Tile-Drained, Agricultural Watershed. Journal of Environmental Quality 36(1):80-90.

Myrold, D.D. 1998. Transformations of Nitrogen. Upper Saddle River, NJ: Prentice Hall.

Nangia, V., P.H. Gowda, D.J. Mulla, and G.R. Sands. 2010 Modeling Impacts of Tile Drain Spacing and Depth on Nitrate-Nitrogen Losses. Vadose Zone Journal 9(1):61-72.

Oorts, K., R. Merckx, E. Grehan, J. Labreuche, and B. Nicolardot. 2007. Determinants of annual fluxes of $\mathrm{CO}_{2}$ and $\mathrm{N}_{2} \mathrm{O}$ in long-term no-tillage and conventional tillage systems in northern France. Soil and Tillage Research 95(1-2):133-148

Osher, L.J., P.A. Matson, and R. Amundson. 2003. Effect of land use change on soil carbon in Hawaii. Biogeochemistry 65(2):213-232.

Patino-Zuniga, L., J. Ceja-Navarro, B. Govaerts, M. LunaGuido, K. Sayre, and L. Dendooven. 2009. The effect of different tillage and residue management practices on soil characteristics, inorganic $\mathrm{N}$ dynamics and emissions of $\mathrm{N}_{2} \mathrm{O}, \mathrm{CO}_{2}$ and $\mathrm{CH}_{4}$ in the central highlands of Mexico: A laboratory study. Plant and Soil 314(1-2):231-241

Paustian, K. 2004. Agricultural mitigation of greenhouse gases: science and policy options. Council on Agricultural Science and Technology (CAST) report, R141 2004, ISBN 1-887383-26-3:120. 
Paustian, K., J. Six, E.T. Elliott, and H.W. Hunt. 2000 Management options for reducing $\mathrm{CO}_{2}$ emissions from agricultural soils. Biogeochemistry 48(1):147-163.

Poch, R.M., J.W. Hopmans, D.E. Rolston, and J.L. McIntyre. 2006. Considerations of a field-scale soil carbon budget for furrow irrigation. Agriculture, Ecosystems and Environment 113(1-4):391-398.

Power, J.F., R. Wiese, and D. Flowerday. 2000. Managing nitrogen for water quality-lessons from Management Systems Evaluation Area. Journal of Environmental Quality 29(2):355-366.

Reicosky, D.C., M.J. Lindstrom, T.E. Schumacher, D.A Lobb, and D.D. Malo. 2005. Tillage-induced $\mathrm{CO}_{2}$ loss across an eroded landscape. Soil and Tillage Research 81(2):183-194.

Rochette, P. 2008. No-till only increases $\mathrm{N}_{2} \mathrm{O}$ emissions in poorly-aerated soils. Soil and Tillage Research 101(1):97-100.

Ronen, D., M. Magaritz, and E. Almon. 1988. Contaminated aquifers are a forgotten component of the global $\mathrm{N}_{2} \mathrm{O}$ budget.

SAS. 2007. SAS user's guide: Statistics. Cary, NC: SAS Institute.

Sawamoto, T., Y. Nakajima, M. Kasuya, H. Tsuruta, and K. Yagi. 2005. Evaluation of emission factors for indirect $\mathrm{N}_{2} \mathrm{O}$ emission due to nitrogen leaching in agro-ecosystems. Geophysical Research Letters 32(3):L03403.

Six, J., S.M. Ogle, FJ. Breidt, R.T. Conant, A.R. Mosier, and K. Paustian. 2004. The potential to mitigate global warming with no-tillage management is only realized when practised in the long term. Global Change Biology 10(2):155-160.

Smith, K., T. Ball, F. Conen, K. Dobbie, J. Massheder, and A. Rey. 2003. Exchange of greenhouse gases between soil and atmosphere: interactions of soil physical factors and biological processes. European Journal of Soil Science 54(4):779-791.
Smith, P., D. Martino, Z. Cai, D. Gwary, H. Janzen, P. Kumar, B. McCarl, S. Ogle, F. O'Mara, C. Rice, B. Scholes, and O. Sirotenko. 2007. Agriculture. In Climate Change 2007: Mitigation. Contribution of Working Group III to the Fourth Assessment Report of the Intergovernmental Panel on Climate Change. Cambridge, United Kingdom and New York: NY.

Smith, P., D. Martino, Z. Cai, D. Gwary, H. Janzen, P. Kumar, B. McCarl, S. Ogle, F. O'Mara, C. Rice, B. Scholes, O. Sirotenko, M. Howden, T. McAllister, G. Pan, V. Romanenkov, U. Schneider, S. Towprayoon, M. Wattenbach, and J. Smith. 2008. Greenhouse gas mitigation in agriculture. Philosophical Transactions of the Royal Society B-Biological Sciences 363(1492).

Soil Survey Staff. 1996. National soil survey handbook. Title 430-VI. USDA Natural Resources Conservation Service. Washington, DC: US Governmental Printing Office.

Sullivan, M.D. 1997. Dissolved organic carbon and soil solution $\mathrm{pH}$ as affected by drainage, tillage, depth and season in an agricultural watershe. Master's thesis, The Ohio State University.

Syakila, A., and C. Kroeze. 2011. The global nitrous oxide budget revisited. Greenhouse Gas Measurement and Management 1(1):17-26.

Ussiri, D.A.N., R. Lal, and M.K. Jarecki. 2009. Nitrous oxide and methane emissions from long-term tillage under a continuous corn cropping system in Ohio. Soil \& Tillage Research 104(2):247-255.

Venterea, R.T., J. Strock, and C. Rosen. 2008. Agricultural management effects on nitrous oxide gas emissions. Proceedings of the Lamberton and Outreach Center Soil and Water Management Field Day, August 13, 2008 Lamberton, MN: USDA Agricultural Research Service.

Whalen, S. 2005. Biogeochemistry of methane exchange between natural wetlands and the atmosphere. Environmental Engineering Science 22(1):73-94. 